\title{
INTERNATIONAL TAXATION OF INCOME IN RUSSIA: BALKAN PERSPECTIVE
}

\author{
Elena KILINKAROVA \\ E-Mail: e.kilinkarova@spbu.ru \\ Associate Professor, Faculty of Law \\ Saint Petersburg State University, Russia
}

\begin{abstract}
This is a study of the current legal framework of international taxation of income between Russia and the Balkan states Albania, Bosnia and Herzegovina, Bulgaria, Croatia, Greece, Kosovo, Montenegro, North Macedonia, Romania, Serbia, Slovenia. The author analyses existing tax treaty provisions, both bilateral and multilateral, with focus on three main issues elimination of international juridical double taxation, international administrative cooperation in tax matters and counteraction to tax avoidance and evasion. For the elimination of international juridical double taxation, the comparative research covers tiebreaker rules, distribute rules and methods for the elimination of double taxation as set in the related double tax treaties. The author identifies similarities and differences in the mechanisms used in relations between Russia and the Balkan states. The analysis of the bilateral and multilateral framework for administrative cooperation in tax matters leads to the conclusion that the exchange of information remains the main form of administrative assistance, with application of other forms being limited due to numerous reservations of the states. The exiting regulation of the counteraction to tax avoidance and evasion does not meet the modern standards and provides for a limited scope of special antiavoidance rules. Six agreements between Russia and the Balkan states are covered by the OECD Multilateral Instrument and the update of the regulation on counteraction to tax avoidance and evasion is foreseeable.
\end{abstract}

Key words: international taxation, double taxation, BEPS, MLI, exchange of information, Russia, Balkan states 


\section{Introduction}

There is no consensus on the content of "international taxation" in the literature on international tax law. Traditionally international taxation refers to treaty provisions relieving international juridical double taxation, but there is also a broader understanding of the term under which it also includes "domestic legislation covering foreign income of residents and domestic income of nonresidents; domestic legislation and treaty provisions containing rules against international tax avoidance and evasion; domestic legislation and treaty provisions relieving international economic double taxation; EC Directives and domestic legislation concerning cross-border direct taxation; and international rules and domestic legislation on the taxation of diplomats, consular officers and officials of intergovernmental organizations" (IBFD International Tax Glossary, 2015).

The author of this article advocates for the broad scope of international taxation encompassing all the "international" aspects of taxation in particular countries related to cross-border activity which involves at least two separate jurisdictions. From this perspective international taxation is covered by both domestic legislation and provisions of treaties, which contain both substantive and procedural tax rules. Usually research focuses on income and capital taxation, but it seems fair to share the view that international tax law extends beyond income and capital taxation, covering other direct taxes, such as inheritance and gift tax, as well as indirect taxes (Roy Rohatgi on International Taxation, 2018, p. 3).

Within this approach the scope of the rules on international taxation in Russia is quite broad and includes domestic legislation and treaty provisions related to taxation of cross-border activity, with the majority of substantive treaty provisions, mainly from double tax treaties, being related to taxation of income and capital.

There are two main dimensions of rules on international taxation of income - the taxation of tax residents on income arising in foreign countries and the taxation of nonresidents on domestic income (i.e., income arising or sourced in the country) (Arnold, 2019, p. 3). The elimination of international double taxation and counteraction to tax avoidance or evasion that result in nontaxation or reduced taxation are the key goals of the existing network of tax treaties. There is also a worldwide consensus on the need to improve administrative co-operation in tax matters, notably through exchange of information and assistance in collection of taxes, for the purpose of preventing tax evasion and avoidance.

This study focuses on the current legal framework of international taxation of income between Russia and the Balkan states - Albania, Bosnia and Herzegovina, Bulgaria, Croatia, Greece, Kosovo, Montenegro, North Macedonia, Romania, Serbia, Slovenia.

Russia has bilateral double tax treaties with the majority of the Balkan states, Albania (1995), Bulgaria (1993), Croatia (1995), Greece (2000), North Macedonia (1997), Romania (1993), Serbia and Montenegro (1995, treaty with 
Federal Republic of Yugoslavia), and Slovenia (1995). The majority of the treaties were signed in 1990s after the renegotiation of the treaties of the former USSR. In general, it took several years for the contracting states to proceed with internal procedures, such as ratification, in order for the treaties to be in effect. An interesting example here is the treaty between Russia and Greece, which was signed in June 2000 and became effective only on 1 January 2008.

Along with double tax treaties, Russia and the majority of Balkan states participate in the joint multilateral tax treaties, including the Convention on Mutual Administrative Assistance in Tax Matters (1988) and Multilateral Convention to Implement Tax Treaty Related Measures to Prevent Base Erosion and Profit Shifting (MLI, Multilateral Instrument) (2017).

The Balkan states have different status in relation to the European Union. Some of the Balkan states are member countries of the European Union Bulgaria, Croatia, Greece, Romania, Slovenia, some are the candidate countries - Albania, Montenegro, North Macedonia, Serbia. However, this difference among the Balkan states is irrelevant for the purposes of international taxation with Russia.

The following contribution presents the analysis of the existing tax treaty provisions between Russia and the Balkan states with focus on three main issues - (1) elimination of international juridical double taxation (section 2), (2) international administrative cooperation in tax matters (section 3) and (3) counteraction to tax avoidance and evasion (section 4). A summary concludes the article (section 5).

\section{Elimination of international juridical double taxation}

\subsection{Elimination of international juridical double taxation: preliminary remarks}

International juridical double taxation can be generally defined as the imposition of comparable taxes in two or more states on the same taxpayer in respect of the same subject matter and for identical periods (OECD Income and Capital Model Convention and Commentary, 2017). International juridical double taxation is opposed to international economic double taxation on the basis of the lack of subject identity. International economic double taxation is the situation that arises when the same economic transaction, item of income or capital is taxed in two or more states during the same period, "but in the hands of different taxpayers" (Klaus Vogel on Double Taxation Conventions, 2015, p. 13-14).

In cross-border situations juridical double taxation is a result of overlapping taxing rights on the same income or capital, which arises as a consequence of conflict in the connecting factors for taxation - residence as the personal base of jurisdiction and the source of income (situs for capital) as the territorial base for jurisdiction, with three types of conflicts usually being identified (Roy Rohatgi on International Taxation, 2018, p. 9-24). 
The most widespread conflict in cross-border activities is the sourceresidence conflict where the income or capital is taxed in one state because the taxpayer is the tax resident of that state, and is taxed in the other state because that other state regards the income or capital as having been sourced there. Another conflict, the residence-residence conflict, can occur when, due to the use of different tests to determine the tax residence in different states, the taxpayer qualifies as a tax resident in two or more states and, consequently, is subject to the taxation of the worldwide income in all of those states. Finally, in the source-source conflict both states treat the taxable income or capital as being sourced in each of the states which gives grounds for taxation in both of the states on the basis of territorial principle of taxation.

The existing legislative and treaty framework focuses on the necessity to eliminate international juridical double taxation due to its harmful effects on the exchange of goods and services and movements of capital, technology and persons. Still the rules typically cover only two types of possible conflicts that lead to international juridical double taxation, source-residence conflict and residence-residence conflict, with the situations of source-source conflict usually remaining unsolved.

Relief from international juridical double taxation may be provided unilaterally, bilaterally or multilaterally. Unilateral measures, provided in the domestic law, are aimed at taxation in the state of tax residence and are usually applicable only to source-residence conflicts. Bilateral and multilateral measures, provided in tax treaties and similar instruments, such as directives of the European Union, provide relief in both source-residence and residenceresidence conflicts.

Russia uses both unilateral and bilateral mechanisms, though the scope of application of the unilateral credit method is limited only to corporate income taxation. Individuals may get relief only through the tax treaty provisions (articles 232 and 311 of the Tax Code of the Russian Federation). Multilateral mechanisms for the elimination of double taxation are not applicable to Russia.

As mentioned above, Russia currently has bilateral double tax treaties applicable to the majority of the Balkan states. Both unilateral and bilateral mechanisms of elimination of international juridical double taxation are available for cross-border activities between Russia and these states. For states with no double tax treaty with Russia, e.g. Bosnia and Herzegovina and Kosovo, only a limited scope of unilateral measures is available, measures which are granted by the states in domestic legislation to their tax residents.

\subsection{Residence-residence conflict}

The residence-residence conflict is possible, due to the different criteria of tax residence that states use in their domestic legislation. For individuals the determination of residence is based on two main tests, the mechanical test which takes into account the number of days of presence in the jurisdiction and the facts-and-circumstances test which looks at the various social and economic connections taxpayers have to the taxing jurisdiction, as well as taxpayers' 
intent with regard to their stay and their connection to other jurisdictions (Ault, Arnold, Cooper, 2020, p. 563).

Russia uses the mechanical test. As a general rule, the individual is regarded as Russian tax resident if he/she is physically present in Russia for at least 183 days during any 12-month period (article 207 of the Tax Code of the Russian Federation). Therefore, the dual residence conflict is possible with those Balkan countries which use the facts-and-circumstances approach to determine individuals' tax residence, i.e. Bosnia and Herzegovina, Bulgaria, Greece, Montenegro, Romania, Serbia, and Slovenia, while the possibility of residence-residence conflict for individuals is excluded for cross-border cases between Russia and three Balkan states, Albania, Croatia and Kosovo, which use mechanical 183-days tests only (IBFD Country Tax Guides for Individual Taxation for the mentioned states, 2020).

For companies two basic approaches are used to determine tax residence. One is to focus on some formal legal connection to the jurisdiction, such as incorporation under the laws of the state, and the other is to concentrate on some of the economic or commercial connections, such as the place of management, principal business location, or, less frequently, the residence of shareholders (Ault, Arnold, Cooper, 2020, p.567)

Since 2015 Russia, in addition to its original criteria of incorporation, determines the tax residence of companies on a management test (article 246.2 of the Tax Code of the Russian Federation), although there is still no publicly available case law of application of the management test residence. Consequently, depending on the real-life circumstances residence-residence conflict in corporate income taxation is possible between Russia and all the Balkan states.

Residence-residence conflict based international juridical double taxation may be solved by the application of the tie-breaker rules set in the article of the double tax treaty on residence. The tie-breaker rules establish tests to determine the single residence state for tax treaty purposes, which, as K. Vogel rightfully highlights, are applicable if two requirements are met - there is a dual residence between the contracting states and single residence state is necessary for the application of the double tax treaty: e.g. which is true for distributive rules of the double tax treaty when one of the two states involved in the cross-border fact is regarded as the state of residence and the other state is considered to be the state of source (Klaus Vogel on Double Taxation Conventions, 2015, p. 238).

The main effect of the tie-breaker rule is that one of the contracting states loses its status as the residence state. Within the application of the double tax treaty, this state may only have the status of the state of source. Still the double tax treaties do not have direct implications for the taxpayer's status and do not impact on "residence" for the purposes of domestic tax law, as the taxpayer generally remains a resident under the provisions of the national tax law (Klaus Vogel on Double Taxation Conventions, 2015, p. 239).

All the bilateral double tax treaties between Russia and the Balkan states contain tie-breaker rules for individuals and persons other than individuals. 
All but one of the tax treaties between Russia and the Balkan states have the same tie-breaker rule for individuals. This rule follows a similar rule of the United Nations model double tax treaty, which in this part is also very close to the OECD model double tax convention. The tie-breaker rule provides a set of priority-ranked tests such as permanent home, center of vital interests, place of habitual abode and nationality (for detailed explanation of the tests refer to Borg Olivier, 2017), to help determine the status of the taxpayer. If none of the tests help to define the state which has closer links with the taxpayer, then the competent authorities of the contracting states are obliged to settle the matter by mutual agreement. All the treaties between Russia and the Balkan states follow this approach. Only the tax treaty with the Federal Republic of Yugoslavia, which is applicable in relation to Serbia and Montenegro, deviates from this rule and excludes nationality from the list of the tests.

The tie-breaker rule for persons other than individuals is more concise and uses only one criterion to break a tie with one of the states of residence. The majority of double tax treaties with the Balkan states, Albania, Bulgaria, Croatia, Greece, Montenegro, Romania, and Serbia, give priority to the place of effective management, while two treaties, those with North Macedonia and Slovenia, give preference to the place of incorporation.

Due to the impact of the Multilateral Convention to Implement Tax Treaty Related Measures to Prevent Base Erosion and Profit Shifting, the current tie-breaker rules for persons other than individuals set in treaties with Romania, Serbia and Slovenia are about to be substituted by the rule according to which the state of residence for the purposes of the treaty shall be determined by the competent authorities by mutual agreement on case-by-case basis with regard to all relevant factors, including the place of effective management and place of incorporation (for detailed analysis of the rules on dual residence of companies under tax treaties refer to Maisto et al., 2018).

\subsection{Source-residence conflict}

The source-residence conflict refers to the situation where taxing rights of two states overlap as the taxpayer is the tax resident in one of the states and the taxable income is sourced from the other state. Both unilateral and bilateral mechanisms are used to provide relief from international juridical double taxation in these cases, unilateral measures being applicable if the case does not fall within the scope of the bilateral mechanism. The underlying concepts of unilateral and bilateral mechanisms differ. The unilateral measures are applied only by the state of residence and allow the taxpayer as a tax resident of that state to take into account, usually in the form of credit or exemption, taxation in the source state while calculating the tax due in the state of residence. Bilateral mechanisms use the allocation of taxing rights between the residence and source states supplemented by the credit or exemption method in the case of shared taxation. Hence credit and exemption methods in international taxation may be applied both as part of the unilateral mechanism and as part of the bilateral mechanism. 
Russia has a limited scope of application of the unilateral relief from the international juridical double taxation, limited to corporate taxation, which applies to all source states, with Balkan states not being exempt. This section focuses on bilateral mechanisms of elimination of the source-residence conflict based international juridical double taxation as set in the relevant double tax treaties between the Russia and the various Balkan states.

For the purpose of elimination of double taxation, double tax treaties establish two categories of rules. The first category encompasses distributive rules, which determine, with regard to different classes of income, rights to tax of the state of source or situs and of the state of residence. These rules may provide for unlimited shared taxation, limited shared taxation, with state of source being granted only limited taxation within the tax rates set in the treaty, and exclusive residence state taxation. The second category covers rules on methods of relief, which the state of residence shall apply in the case of shared taxation between the two states.

The double tax treaties between Russia and the various Balkan states provide special distributive rules for the following classes of income - income from immovable property, business profits, income from international transport, dividends, interest, royalties, capital gains, income from independent and dependent personal services, director' fees, income of artists and sportsmen, pensions, income from government service, and certain types of income of students and trainees, professors, teachers and researchers, with a separate class of the "other income". The existing tax treaties with the Balkan states in general follow the same pattern in allocating the taxing rights between the state of residence and the state of source, though some deviations from the common approach may be found.

The treaties provide for unlimited shared taxation for quite a wide range of types of income, such as income from immovable property and gains from the alienation of such property, business profits related to a permanent establishment in the state of source and gains from the alienation of such a permanent establishment, income from independent personal services related to the fixed base, dependent personal services (with several exemptions provided), director' fees, and income of artists and sportsmen.

The limited shared taxation is provided for the three types of "passive" income - dividends, interests and royalties. It is not possible to be sure which of the model acts was used for negotiation of the treaties with the Balkan states, but, in passive income, the treaties seem to follow the United Nations model convention, which provides for the limited taxation in respect of dividends, interest and royalties while OECD model convention recommends limited shared taxation only for dividends and interest, leaving the royalties for exclusive taxation in the state of residence.

The treaty tax rates for passive types of income vary from treaty to treaty, with $10 \%$ and $15 \%$ being the most often used. The withholding tax rates for these three types of income are displayed in the table 1. 
Table 1. Withholding tax rates in the state of source for dividends, interest and royalties in accordance with double tax treaties between Russia and the Balkan states.

\begin{tabular}{|l|c|c|c|}
\hline & Dividends & Interest & Royalties \\
\hline Albania & $10 \%$ & $10 \%$ & $10 \%$ \\
\hline Bulgaria & $15 \%$ & $\begin{array}{c}15 \% \\
(0 \% \text { for several } \\
\text { exemptions })\end{array}$ & $15 \%$ \\
\hline Croatia & $5 \%$ and $10 \%$ & $10 \%$ & $10 \%$ \\
\hline Greece & $5 \%$ and $10 \%$ & $7 \%$ & $7 \%$ \\
\hline Montenegro & $5 \%$ and $15 \%$ & $10 \%$ & $10 \%$ \\
\hline $\begin{array}{l}\text { North } \\
\text { Macedonia }\end{array}$ & $10 \%$ & $10 \%$ & $10 \%$ \\
\hline Romania & $15 \%$ & $\begin{array}{c}15 \% \\
(0 \% \text { for several } \\
\text { exemptions })\end{array}$ & $10 \%$ \\
\hline Serbia & $5 \%$ and $10 \%$ & $10 \%$ & $10 \%$ \\
\hline Slovenia & $10 \%$ & $10 \%$ & $10 \%$ \\
\hline
\end{tabular}

Some of the types of income are excluded from taxation in the source state, for example, business profits that are not attributable to a permanent establishment in the state of source and pensions. The exclusive right to taxation is also given to the state of residence in respect to "other income" not dealt with in the article on specific type of income.

In the case of the shared taxation the international juridical double taxation is eliminated by the obligatory relief provided by the state of residence. The existing model conventions provide for the two possible methods, exemption and credit. The contracting states are free to choose any double tax relief method, or combination thereof, and reciprocity is not required.

Russia and the Balkan states are unanimous in their choice of the method of the elimination of double taxation, choosing the ordinary tax credit. Credit is a method under which taxes imposed on foreign income may be credited against or deducted from domestic tax on that income. The ordinary tax credit implies that credit is limited to the amount of domestic tax that would be imposed on the foreign-source income if no credit for foreign tax were given. However, the excess is not refunded if the tax in the state of source is higher than in the state of residence.

Tax treaties applicable to Albania, North Macedonia, Serbia and Montenegro additionally provide for the possibility of ordinary tax credit with progression, when, if in accordance with any provision of the double tax treaty, income derived or capital owned by a resident of the state is exempt from tax in that state, the state of residence may nevertheless, in calculating the amount of tax on the remaining income or capital of such resident, take into account the 
exempted income or capital for the purposes of defining the applicable tax rate from the progressive scale of tax rates.

\section{International administrative cooperation in the field of taxation}

The tax jurisdiction has its limits, with the international administrative cooperation being a very important part of tax administration, as the states are not allowed to conduct tax investigations in the territory of the other states and cannot oblige the other states to provide requested information. So, treaty provisions are usually needed as the framework for international administrative cooperation in the field of taxation (for detailed information on Russian framework for the exchange of information refer to Roudomanov, Kadet, 2020).

All of the existing double tax treaties between Russia and the Balkans states have special provisions for the exchange of information, with the rules being similar in all of the treaties, - these are articles 26 or 27 of the double tax treaties.

The states have opted to apply "major information clause" -it means that the double tax treaties impose on the parties the obligation to exchange such information as is necessary for carrying out not only the provisions of the treaty but also of the domestic laws of the contracting states concerning taxes covered by the treaty. As the exchange of information is not limited for information which is necessary for carrying out the double tax treaty only, the personal scope of the article on exchange of information is wider than the personal scope of the double tax treaty itself - and is not limited to persons who are tax residents in one or both of the contracting states. The double tax treaties provide that contracting states can exchange information on any taxpayer regardless of the status of tax resident in one of the contracting states.

However, Russia and the Balkan states have not opted to widen the substantive scope of the article on exchange of information as, for example, provided by the OECD model convention. The states follow the United Nations model convention and impose the obligation to exchange information only in respect of the taxes covered by the double tax treaty, while under the OECD model states may exchange information in respect of all taxes, not only taxes specified in the treaty, which are usually taxes on income and capital.

Double tax treaties between Russia and the Balkan states demand the states to treat any information received as secret in the same manner as information obtained under the domestic law of the state. The competent authorities may disclose the information only to persons or authorities, including administrative bodies and courts, involved in the assessment, collection and enforcement of the taxes covered. This information may be used only for specific tax purposes. However, despite special requirements on secrecy, the information received may become publicly available in course of the public court proceedings or in judicial decisions.

Finally, the analyzed articles set limitations on the exchange of information. The first limitation is connected with the existing restrictions in 
tax procedures. The obligation to exchange information does not demand administrative measures be carried out beyond the limits set in the laws and administrative practice of the state, and, on the basis of reciprocity, to supply information which is not obtainable under the laws or the normal course of the administration of the other contracting state. The second limitation relates to prohibition of information being supplied which would disclose any trade, business, industrial, commercial or professional secret or trade process, or information, the disclosure of which would be contrary to public policy.

These are the key provisions of the double tax treaties between Russia and the Balkan states. As the treaties were negotiated and signed in 1990's, it is not surprising that they do not contain all the rules that could be found in the current versions of the existing double tax treaty models. For instance, the international administrative cooperation under double tax treaties between Russia and the Balkan states is limited to exchange of information. There are no rules on assistance in the collection of taxes in the treaties - the rules that were incorporated in the OECD and United Nations models in the beginning of 2000's.

Along with double tax treaties international administrative cooperation between Russia and Balkan states may be grounded on application of the multilateral Convention on Mutual Administrative Assistance in Tax Matters (Convention) which was developed jointly by the OECD and the Council of Europe in 1988 and amended by Protocol in 2010. One hundred forty-one jurisdictions currently participate in the Convention, including Russia since July 2015, and the majority of the Balkan states. Some of the Balkan states already have experience in application of the Convention, including Slovenia, since June 2011; Albania since December 2013; Greece, since September 2013; Croatia, since June 2014; Romania, since November 2014 and Bulgaria, since July 2016. Some of the states are the newcomers such as Serbia, since December 2019; North Macedonia, since January 2020; Montenegro, since May 2020, and Bosnia and Herzegovina, since January 2021. At the moment only Kosovo, among the Balkan states, is not a participant to this multilateral Convention.

The Convention on Mutual Administrative Assistance in Tax Matters obliges the parties to provide administrative assistance to each other in tax matters, with such assistance comprising of exchange of information, including simultaneous tax examinations and participation in tax examinations abroad, assistance in recovery, including measures of conservancy, and service of documents (article 1 of the Convention).

The personal scope of the Convention is quite wide, but does not cover all the taxpayers. A party shall provide administrative assistance whether the person affected is a resident or national of a party or of any other state (article 1(3) of the Convention). The substantial scope of the Convention covers all the taxes (except for customs duties) and compulsory social security contributions (article 2 of the Convention) and is therefore wider than the scope of the rules on exchange of information under existing double tax treaties of Russia with the Balkan states. 
Available forms of assistance include different forms of exchange of information, such as exchange of information on request, automatic exchange of information, spontaneous exchange of information, simultaneous tax examinations, tax examinations abroad; tax recovery and document service. The Convention on Mutual Administrative Assistance in Tax Matters provides for wide possibilities of international administrative cooperation in the field of taxation, but it also gives the states the right to make reservations (article 30 of the Convention). Russia and the Balkan states have used this opportunity, thus limiting the scope of the application of the treaty. ${ }^{1}$ As a result, the majority of the states limit the taxes covered by the treaty and reserve the right not to provide assistance in some of the forms. For instance, Russia, Albania, Croatia, Montenegro, North Macedonia, Serbia, and Slovenia limit assistance in the recovery of any tax claim or in the recovery of an administrative fine, and Albania, Croatia, Montenegro, North Macedonia, Slovenia limit the assistance in the service of documents, while Montenegro does not participate in tax examination abroad.

Although Russia and the majority of the Balkan states limit the possible forms of international tax cooperation within the Convention, the states tend to use the possibilities of the automatic exchange of information with respect to financial accounts and country-by-country reports.

Under the Common Reporting Standard Multilateral Competent Authority Agreement several bilateral exchange relationships are activated between Russia and some of the Balkan states. As of August 2020, Russia sends information to Croatia, Greece and Slovenia, while Croatia, Greece, Romania and Slovenia send information to Russia (Activated exchange relationships for CRS information. Retrieved on November 29, 2020 from the OECD website, https://www.oecd.org/tax/automatic-exchange/international-framework-forthe-crs/exchange-relationships). Under the Country-by-country Multilateral Competent Authority Agreement the situation is very much alike. As of August 2020 Russia sends information to Croatia, Greece and Slovenia, while Croatia, Greece, Romania and Slovenia send information to Russia (Country-bycountry reporting exchange relationships. Retrieved on November 29, 2020 from the OECD website, https://www.oecd.org/tax/automaticexchange/country-by-country-exchange-relationships.htm).

\section{Counteraction to tax avoidance and evasion.}

The academic literature debates the concepts of tax avoidance and tax evasion. According to the most wide-spread approach, the term "tax avoidance", which may be used to refer to acceptable forms of behavior, such as tax planning, is more often used in a pejorative sense to refer to something

1 The full list of declarations and reservations to the Convention on mutual administrative assistance in tax matters is available at the Council of Europe web-site: https://www.coe.int/en/web/conventions/full-list//conventions/treaty/127/de-clarations 
considered unacceptable, or illegitimate, but not, in general, illegal. In other words, tax avoidance is often within the letter of the law, but against the spirit of the law. Tax evasion, by contrast, may be characterized as intentional illegal behavior, or as behavior involving a direct violation of tax law, in order to escape payment of tax (IBFD International Tax Glossary, 2015).

Counteraction to tax avoidance and evasion has been one of the key issues in the world's political agenda on international taxation for the last decade, mainly due to the OECD Base Erosion and Profit Shifting Project (BEPS), which aims to put an end to tax avoidance strategies that exploit gaps and mismatches in tax rules. For Russia, significant changes in regulation of international taxation are connected not only with its participation in the OECD BEPS initiative, but also with the realization of the governmental policy of "deoffshorization" of the Russian economy which was launched in 2012-2013, at approximately the same time as the OECD BEPS Project.

Counteraction to tax avoidance and evasion in international taxation may be based on the application of general and special anti-avoidance rules, set in both national legislation and double tax treaties. This section of the article focuses on the respective provisions of the treaties between Russia and the Balkan states.

The analysis of the rules provided by the bilateral double tax treaties between Russia and the Balkan states are brief as the treaties do not have any general anti-avoidance rules with beneficial owner clause for articles on dividends, interest and royalties being generally the one and only applicable special anti-avoidance rule.

However, the situation is about to change, due to the participation of Russia and the majority of the Balkan states in the MLI, Multilateral Instrument, which is one of the major outcomes of the OECD BEPS Project and contains anti-avoidance measures of a general and special scope of application. The MLI is a multilateral convention that allows governments to modify existing bilateral tax treaties in a synchronized and efficient manner to implement the tax treaty measures developed during the BEPS Project, without the need to renegotiating each treaty bilaterally. The MLI is undoubtfully one of the most complex legal instruments in the field of international tax law. The Multilateral Instrument is the independent multilateral treaty that applies to relations regulated by the double tax treaty as lex posterior.

For the MLI to have an impact on the double tax treaty the following conditions must be met: (1) both of the contracting states of the double tax treaty are the signatories to the MLI to which it is in effect, and (2) both of the contracting states put the related double tax treaty in the list of "covered tax agreements" (articles 1 and 2 of the MLI). Due to the existence of different types of provisions in the MLI - obligatory minimum standard and optional provision, the extent of the impact of the MLI on the certain double tax treaty depends on the quantity of "matches" in reservations and notifications of the related contracting states. As of October 20, 2020, Russia, Albania, Bosnia and Herzegovina, Bulgaria, Croatia, Greece, North Macedonia, Romania, Serbia and Slovenia are the signatories to the MLI. 
Albania, Bulgaria, Croatia, Greece, North Macedonia, Romania, Serbia and Slovenia have included the tax treaty with Russia in their list of the covered tax agreements. However, Russia listed only 66 of its agreements as covered by the MLI, leaving nearly 20 of the double tax treaties outside the scope of the agreement. There were no official comments with explanation for this position. Not all double tax treaties with the Balkan states are in the Russian list of covered tax agreements. Russia included treaties with Bulgaria, Croatia, Greece, Romania, Serbia and Slovenia. Due to the mechanism of the application of the MLI, only treaties with these states will be affected by the MLI. Several treaties with the Balkan states, such as Albania and North Macedonia, remain untouched.

In order to assess the extent of the changes of the regulation, the positions of the signatories as provided in the lists of reservations and notification at the time of signature of the MLI must be compared. For example, although Russia opted for the application of the new tie-breaker rule for persons other than individuals, provisions of only three double tax treaties, with Romania, Serbia and Slovenia, will be substituted, while Bulgaria, Croatia and Greece have opted not to apply the article of the MLI on dual resident entities.

The detailed analysis of the positions of Russia and the Balkan states is out of the scope of this article, but due to the existence of the obligatory minimum standard provisions we may be sure that the regulation provided by the double tax treaties will be supplemented by the new preamble to the double tax treaty convention, with focus on the necessity not only to avoid double taxation but also to prevent tax avoidance and tax evasion (article 6 of the MLI), the use of the principle purpose test as the general anti-avoidance rule (article 7 of the MLI) and rules of mutual agreement procedure (article 16 of the MLI).

\section{Conclusion}

The rules on international taxation of income between Russia and the Balkan states are set both in domestic legislation of the states and tax treaties, with double tax treaties being in force in relations between Russia and nine Balkan states, Albania, Bulgaria, Croatia, Greece, Montenegro, North Macedonia, Romania, Serbia and Slovenia. Alongside with double tax treaties two key multilateral tax treaties are applicable to relations between Russia and the majority of the Balkan states - Mutual Administrative Assistance Convention and the MLI.

The analysis of the existing tax treaty provisions between Russia and the Balkan states focus on three main issues, the elimination of international juridical double taxation, international administrative cooperation in tax matters, and counteraction to tax avoidance and evasion.

The following conclusions are made. International juridical double taxation in relations with the majority of the Balkan states is eliminated with the help of unilateral and bilateral mechanisms, while in relations between Russia and two states, Bosnia and Herzegovina and Kosovo, only unilateral 
measures are available which, for Russian tax residents, are limited to the application of the credit method in corporate income taxation.

Existing double tax treaties between Russian and the Balkan states unanimously deal with residence-residence type of conflict for individuals, but different approaches are used in corporate taxation with place of effective management or place of incorporation being used as the tie-breaker criteria. Due to the impact of the MLI in relations of Russia with three states, Romania, Serbia and Slovenia, the case-by-case approach based on mutual agreement procedure will soon substitute the existing rules. The distributive rules of the double tax treaties generally follow the same pattern in allocation of the taxing rights between the state of residence and the state of source. Russia and the Balkan states choose the same method of elimination of double taxation in their tax treaties, the ordinary tax credit, though several treaties additionally provide for the possibility of the ordinary tax credit with progression.

The legal grounds for administrative cooperation are the double tax treaties and the Multilateral Mutual Administrative Assistance Convention, which set grounds for international cooperation between Russia and almost all of the Balkan states. Still the scope of the application of the this Convention is limited due to the reservations of various states. Exchange of information remains the main form of administrative cooperation in the field of taxation.

The existing double tax treaty network provides for a limited scope of special anti-avoidance rules, with no general anti-avoidance rules set. The MLI is about to change this situation, but only agreements with six Balkan states are covered by the MLI. For the rest of the Balkan states the situation remains unchanged, and legal framework for counteraction to tax avoidance and evasion does not meet the modern standards.

\section{References}

\section{Books and articles}

Arnold B.J. (2019) International Tax Primer, $4^{\text {th }}$ ed. The Netherlands: Wolters Kluwer.

Ault H.J., Arnold B.J., Cooper G.S. (2020). Comparative Income Taxation: A Structural Analysis. $4^{\text {th }}$ ed. The Netherlands: Kluwer Law International.

Borg Olivier T. (2017) Developments in the Analysis of the Tie-Breaker Rule for Individuals Under Article 4 (1) OECD. Intertax, 2017, 45 (1).

IBFD International Tax Glossary. (2015). Rogers-Glabush J. (Ed.) The Netherlands: IBFD.

IBFD Country Tax Guides for Individual Taxation. Retrieved November 29, 2020 from IBFD Tax Research Platform https://research.ibfd.org

Klaus Vogel on Double Taxation Conventions (2015). Reimmer E., Rust A. (Eds). The Netherlands: Kluwer Law International.

Maisto G. et al. (2018). Dual Residence of Companies under Tax Treaties. International Tax Studies. 1. 
Model Tax Convention on Income and on Capital: Condensed Version 2017 (2017). Paris: OECD Publishing

Roudomanov N., Kadet A. (2020) National Report for Russia. In Cahier de Droit Fiscal International. Volume 105 B: Exchange of Information: issues, use and collaboration. The Netherlands: IFA.

Roy Rohatgi on International Taxation. Volume 1: Principles (2018). Ostaszewska O., Obuoforibo B.R. (Eds.). The Netherlands: IBFD.

United Nations Model Double Taxation Convention between Developed and Developing Countries (2017). United Nations. Retrieved November 29, 2020 from IBFD Tax Research Platform https://research.ibfd.org

\section{Legal acts}

Agreement between the Government of the Republic of Croatia and the Government of the Russian Federation for the Avoidance of Double Taxation with respect to Taxes on Income and on Capital, as of 2 October 1995

Agreement between the Government of the Russian Federation and the Government of the Republic of Macedonia for the Avoidance of Double Taxation with respect to Taxes on Income and on Capital, as of 21 October 1997

Convention between the Government of Romania and the Government of the Russian Federation for the Avoidance of Double Taxation with respect to Taxes on Income and on Capital, as of 27 September 1993

Convention between the Government of the Hellenic Republic and the Government of the Russian Federation for the Avoidance of Double Taxation and for the Prevention of Fiscal Evasion with respect to Taxes on Income and on Capital, as of 26 June 2000

Convention between the Government of the Russian Federation and the Government of the Republic of Albania for the Avoidance of Double Taxation with respect to Taxes on Income and on Capital, of 11 April 1995

Convention between the Government of the Russian Federation and the Government of the Republic of Slovenia for the Avoidance of Double Taxation with respect to Taxes on Income and Capital, as of 29 September 1995

Convention between the Republic of Bulgaria and the Government of the Russian Federation and the Prevention of Fiscal Evasion with respect to Taxes on Income and Capital Tax, of 8 June 1993

Convention on Mutual Administrative Assistance in Tax Matters, of 25 January 1988 (as amended)

Multilateral Competent Authority Agreement on Automatic Exchange of Financial Account Information, of October 2014 
Multilateral Competent Authority Agreement on the Exchange of Country-byCountry Reports, of 27 January 2016

Multilateral Convention to Implement Treaty Related Measures to Prevent Base Erosion and Profit Shifting, of 7 June 2017 with reservations and notifications of Albania, Bosnia and Herzegovina, Bulgaria, Croatia, Greece, North Macedonia, Romania, Russia, Serbia, Slovenia

Tax Code of the Russian Federation, part 2, of 5 August, 2000 (as amended)

The Convention between the Government of the Federal Republic of Yugoslavia and the Government of the Russian Federation for the Avoidance of Double Taxation with respect to Taxes on Income and Capital, as of 12 October 1995 